\title{
Paul Rasse, Le théâtre dans l'espace public : Avignon Off
} Édisud, Aix en Provence, 2003

\section{OpenEdition Journals}

Édition électronique

URL : http://journals.openedition.org/edc/229

DOI : 10.4000/edc.229

ISSN : 2101-0366

\section{Éditeur}

Université de Lille

\section{Édition imprimée}

Date de publication : 1 décembre 2004

Pagination : 191

ISBN : 2-9514961-5-X

ISSN : $1270-6841$

Référence électronique

"Paul Rasse, Le théâtre dans l'espace public : Avignon Off », Études de communication [En ligne], 27 | 2004, mis en ligne le 12 mars 2009, consulté le 22 septembre 2020. URL : http:// journals.openedition.org/edc/229; DOI : https://doi.org/10.4000/edc.229

Ce document a été généré automatiquement le 22 septembre 2020

(c) Tous droits réservés 


\section{Paul Rasse, Le théâtre dans l'espace public : Avignon Off}

Édisud, Aix en Provence, 2003

\section{RÉFÉRENCE}

Le théâtre dans l'espace public : Avignon Off. Édisud, Aix en Provence, 2003.

1 Ce n'est pas tant le théâtre dans l'espace public (comme dit le titre de l'ouvrage), que le théâtre comme espace public que l'ouvrage de P. Rasse parcourt. Le festival off d'Avignon fait même figure d'idéal-type d'un espace public régénéré : pour l'auteur, là s'invente un nouveau théâtre où les médiations traditionnelles s'effacent, où les artistes sont confrontés - en prise directe - au jugement esthétique du public et des professionnels, où le spectateur est actif de bout en bout, acteur cultivé associant intelligence et passion, au cœur de cet espace public réticulaire ouvert. Le Off est un point d'appui pour penser plus largement les nouveaux rapports à l'art et à la création qui sont à l'œuvre aujourd'hui. 